\title{
Letter
}

\section{What role for conservation in culture? A response to Schneider}

Schneider makes a much-needed case for rethinking the role of culture in conservation. Importantly, she advocates a more expansive understanding of culture than conservationists have previously deployed: one that addresses the full complement of cultural values that shape people's lives. To accommodate such values, she suggests, conservationists should engage more widely with the social sciences and humanities, 'with religious and cultural institutions, and perhaps even with shamans, sorcerers, witches and wizards' (Schneider, 2018, p. 200).

As a discipline that has long engaged with such magicaland often politically and scientifically marginalized-figures, socio-cultural anthropology can bring a lot to this conversation. But more than just filling gaps in conservationists' knowledge, anthropological insights can push conservation to reframe some basic assumptions about culture, conservation and the relationship between them.

Firstly, culture is not only or predominantly the sum of its values. Values represent ideal models but they cannot fully capture the material, economic, political and social realities, and inconsistencies, of people's lives. Secondly, cultures are not homogenous, discrete and unchanging, but heterogeneous, porous and always evolving-often through interaction with other parties and cultural forms, from the state to Christianity to Western science. Moreover, cultural values and practices are not uniformly accepted or followed: they can also be contested, reworked or rejected.

But conservation isn't static, bounded or homogeneous either. As anthropologists have shown, conservation ideals and policies are inevitably transformed, taken apart and appropriated in specific contexts. Global conservation discourses and policies are often co-opted and reformulated by national or regional governments (Hathaway, 2013), reimagined by local elites (Shah, 2010) or scientists (Lowe, 2006), and domesticated by local systems of exchange and reciprocity (West, 2006).

It is thus vital to acknowledge that both culture and conservation are dynamic, shifting entities that produce new, sometimes unexpected, values, relations and outcomes through their interaction. Conservation interventions can, for example, feed into socio-political tensions and inequalities (Anderson \& Berglund, 2003) and forge new regimes of governance, evaluation, and rights to life and death (Duffy, 2014; Bocci, 2017). They can also generate new conceptual imaginaries (Brightman, 2012), values (Kockelmanm, 2016) and alliances (Conklin \& Graham, 1995).

It is at this third, conceptual level that conservation interventions have the greatest potential to enact profound, longterm change by creating new, culturally relevant possibilities for thought and action. For this to work, however, it is not enough simply to incorporate cultural values into conservation. Rather, we must also consider how conservation values, strategies and priorities can be incorporated into and remoulded to fit particular socio-cultural contexts. The people with whom conservationists work are not blank slates that simply need education or incentivization. Their lives and decisions are shaped by multiple social, cultural, political and economic factors, of which conservation is only one. The question we thus need to ask is not only what role culture (qua values) can play in conservation, but what role conservation can play in the cultures it encounters.

Liana Chua Anthropology, Department of Social and Political Sciences, Brunel University London, Uxbridge, UB8 3PH, UK. E-mail liana.chua@brunel.ac.uk

\section{References}

Anderson, D.G. \& Berglund, E. (eds) (2003) Ethnographies of Conservation: Environmentalism and the Distribution of Privilege. Berghahn Books, New York, USA.

Bocci, P. (2017) Tangles of care: killing goats to save tortoises on the Galápagos Islands. Cultural Anthropology, 32, 424-449.

Brightman, M. (2012) Maps and clocks in Amazonia: the things of conversion and conservation. Journal of the Royal Anthropological Institute, 18, 554-571.

Conklin, B.A. \& Graham, L.R. (1995) The shifting middle ground: Amazonian Indians and eco-politics. American Anthropologist, 97, 695-710.

DufFy, R. (2014) Waging a war to save biodiversity: the rise of militarized conservation. International Affairs, 90, 819-834.

Hathaway, M. (2013) Environmental Winds: Making the Global in Southwest China. University of California Press, Berkeley, USA.

Kockelman, P. (2016) The Chicken and the Quetzal: Incommensurate Ontologies and Portable Values in Guatemala's Cloud Forest. Duke University Press, Durham, USA.

Lowe, C. (2006) Wild Profusion: Biodiversity Conservation in an Indonesian Archipelago. Princeton University Press, Princeton, USA.

SChneider, H. (2018) What role for culture in conservation? Oryx, 52, 199-200.

$\mathrm{S}_{\mathrm{HAH}}$, A. (2010) In the Shadows of the State: Indigenous Politics, Environmentalism, and Insurgency in Jharkhand, India. Duke University Press, Durham, USA.

West, P. (2006) Conservation is our Government Now: The Politics of Ecology in Papua New Guinea. Duke University Press, Durham, USA. 